\title{
Serum osteocalcin levels in diabetes mellitus: analysis of the type of diabetes and microvascular complications
}

\author{
P. Pietschmann ${ }^{1}$, G. Schernthaner ${ }^{2}$ and W. Woloszczuk ${ }^{3}$ \\ ${ }^{1}$ Department of Medicine II, University of Vienna, ${ }^{2}$ Department of Medicine I, Rudolfstiftung Hospital, and \\ ${ }^{3}$ Ludwig Boltzmann Institute of Clinical Endocrinology, Vienna, Austria
}

\begin{abstract}
Summary. Recent studies indicate that serum levels of osteocalcin, a 49-aminoacid bone matrix protein, are a biochemical marker of bone formation. In order to study bone metabolism in diabetes mellitus, in 28 patients with Type 1 (insulin-dependent) diabetes mellitus, in 38 patients with Type 2 (noninsulin-dependent) diabetes mellitus and two control groups, matched for Type 1 and Type 2 diabetic patients, respectively, serum levels of osteocalcin, parathyroid hormone and 25 hydroxy vitamin $\mathrm{D}$ were measured by radioimmunoassay. Whereas in Type 1 diabetic patients and control subjects serum levels of osteocalcin and 25 hydroxy vitamin D were not statistically different, serum osteocalcin and 25 hydroxy vitamin D levels were significantly decreased in Type 2 diabetic patients when compared with corresponding control subjects ( $p<0.03$ and $p<0.001$, respectively). Independent of the type of diabetes, serum parathyroid hormone levels were comparable in diabetic patients and matched control subjects.
\end{abstract}

Serum osteocalcin levels were significantly lower in Type 1 diabetic patients with retinopathy and/or proteinuria than in Type 1 diabetic patients without microangiopathy $(p<0.05)$. Whereas serum parathyroid hormone levels in Type 2 diabetic patients with retinopathy and/or proteinuria were significantly increased $(p<0.02), 25$ hydroxy vitamin D levels were decreased $(p<0.02)$ when compared with Type 2 diabetic patients without microangiopathy. Our data give evidence of a vitamin $\mathrm{D}$ deficiency and a decreased bone formation in patients with Type 2 diabetes mellitus. In Type 1 diabetes mellitus bone formation as reflected by serum osteocalcin levels is influenced by the presence or absence of microangiopathic complications.

Key word: Diabetes mellitus, osteocalcin, bone GLA-protein, parathyroid hormone, bone formation, $25 \mathrm{OH}$ vitamin D.
Osteopenia has been recognized as a general feature of diabetes mellitus. In 1927, osteopenia was described radiographically in children with diabetes mellitus [1]. Menczel et al. in a large scale radiologic study demonstrated an increased incidence of osteoporosis and hip fractures in diabetic patients [2]; however, regarding the osteoporosis in Type 2 (non-insulin-dependent) diabetes mellitus in the literature some controversy exists [3, 4]. Using photonabsorptiometry, a decreased bone mineral content was found in Type 1 (insulin-dependent) and insulin treated Type 2 diabetic patients [5-10]; whereas, in those patients treated with oral hypoglycaemic agents, both an increased and a decreased bone mass has been reported [3,11].

Osteocalcin (OC, bone GLA-protein) is a 49-amino acid bone matrix protein which is released into the blood and can be measured by radioimmunoassay [12]. Serum OC levels have been found to represent the de novo synthesis of $\mathrm{OC}$ by osteoblasts [13].

Clinical evidence indicates that serum OC levels are a useful non-invasive biochemical parameter of bone formation [14]. In order to gain further insights into the pathophysiology of bone metabolism in diabetes mellitus, we measured serum levels of osteocalcin, parathyroid hormone (PTH) and 25 hydroxy vitamin D (25 OH Vit. D) in Type 1 and Type 2 diabetic patients.

\section{Subjects and methods}

Twenty-eight patients with Type 1 diabetes mellitus and 38 patients with Type 2 diabetes mellitus were studied. Clinical characteristics of diabetic patients are given in Table 1, in all patients serum creatinine levels, as well as the serum levels of calcium and phosphorus, were in the normal range. No diabetic patient took any medication known to influence bone metabolism. The patients had no clinical signs or symptoms of osteoporosis. In the diabetic patients, the presence or absence of diabetic retinopathy was assessed by funduscopy and fluorescein angiography; urinary protein excretion was determined by the biuret method. Results obtained in the diabetic patients were compared with two control groups, sex- and age matched for Type 1 and Type 2 diabetic patients, respectively (Table 1). All control subjects were apparently healthy, led normal life styles and had normal dietary 
Table 1. Clinical characteristics of the Type 1 (insulin-dependent) (DM I) and Type 2 (non-insulin-dependent) (DM II) diabetic patients and the corresponding control groups (CO I/CO II)

\begin{tabular}{|c|c|c|c|c|c|c|c|c|}
\hline & $\begin{array}{l}\text { Male/ } \\
\text { female }\end{array}$ & $\begin{array}{l}\text { Age } \\
\text { (years) }\end{array}$ & $\mathrm{BMI}^{\mathrm{a}}$ & $\begin{array}{l}\text { Diabetes } \\
\text { duration } \\
\text { (years) }\end{array}$ & $\begin{array}{l}\mathrm{HbA}_{1 \mathrm{C}^{b}} \\
(\%)\end{array}$ & $\begin{array}{l}\text { Serum } \\
\text { creatinine } \\
(\mathrm{mg} / \mathrm{dl})\end{array}$ & $\begin{array}{l}\text { Creatinine } \\
\text { clearance } \\
(\mathrm{ml} / \mathrm{min})\end{array}$ & $\begin{array}{l}\text { Urinary } \\
\text { protein } \\
\text { excretion } \\
(\mathrm{mg} / 24 \mathrm{~h})\end{array}$ \\
\hline DM I & $13 / 15$ & $28 \pm 1$ & $24 \pm 1$ & $12 \pm 2$ & $8.7 \pm 0.4$ & $0.9 \pm 0.05$ & $88 \pm 7$ & $623 \pm 285$ \\
\hline $\mathrm{COI}$ & $9 / 11$ & $31 \pm 3$ & $23 \pm 1$ & & & $0.9 \pm 0.04$ & & \\
\hline DM II & $25 / 13$ & $62 \pm 2$ & $26 \pm 1$ & $13 \pm 1$ & $8.8 \pm 0.3$ & $1.0 \pm 0.07$ & $78 \pm 6$ & $490 \pm 207$ \\
\hline CO II & $11 / 6$ & $62 \pm 3$ & $25 \pm 1$ & & & $1.0 \pm 0.06$ & & \\
\hline
\end{tabular}

${ }^{\mathrm{a}}$ body mass index $\left(\mathrm{kg} / \mathrm{m}^{2}\right)$; ${ }^{\mathrm{b}}$ glycosylated hemoglobin $\mathrm{A}_{1 \mathrm{c}}$ (normal range $<6 \%$ ); data are given as the mean $\pm \mathrm{SEM}$

Table 2. Serum levels of bilirubin, alkaline phosphatase (AP), aspartate aminotransferase (GOT), alanine aminotransferase (GPT), $\gamma$ glutamyltansferase $(\gamma \mathrm{GT})$ calcium $(\mathrm{Ca})$ and phosphorus $(\mathrm{Ph})$ in Type 1 (DM I) and Type 2 (DM II) diabetic patients and corresponding control subjects (CO I/CO II). The values are given as the median value, the lower and the upper quartile

\begin{tabular}{|c|c|c|c|c|c|c|c|}
\hline & $\begin{array}{l}\text { Bilirubin } \\
(\mathrm{mg} / \mathrm{dl})\end{array}$ & $\begin{array}{l}\text { AP } \\
(U / 1)\end{array}$ & $\begin{array}{l}\text { GOT } \\
(\mathrm{U} / 1)\end{array}$ & $\begin{array}{l}\text { GPT } \\
(\mathrm{U} / 1)\end{array}$ & $\begin{array}{l}\gamma \mathrm{GT} \\
(\mathrm{U} / \mathrm{l})\end{array}$ & $\begin{array}{l}\mathrm{Ca} \\
(\mathrm{mmol} / \mathrm{l})\end{array}$ & $\begin{array}{l}\mathrm{Ph} \\
(\mathrm{mmol} / \mathrm{l})\end{array}$ \\
\hline DM I & $0.5(0.3-0.8)$ & $112(82-136)^{\mathrm{a}}$ & $7.5(6-11)$ & $10.5(9-16)^{\mathrm{b}}$ & $7.5(5-14.8)$ & $2.3(2.2-2.4)$ & $(1.05-1.3)$ \\
\hline $\mathrm{COI}$ & $0.6(0.3-0.8)$ & $84(71-112)^{\mathrm{a}}$ & $7 \quad(6-10)$ & $8.5(6.8-11)^{b}$ & $7.5(6-12.8)$ & $2.3(2.2-2.4)$ & $1.2(1.05-1.35)$ \\
\hline CO II & $0.5(0.4-0.6)$ & $119(93-163)$ & $(6-15)$ & $(8-21)$ & $(8-20)$ & $2.4(2.4-2.5)^{\mathrm{c}}$ & $1.1 \quad(0.9-1.2)$ \\
\hline
\end{tabular}

${ }^{\mathrm{a}} p<0.04 ;{ }^{\mathrm{b}} p<0.03 ;{ }^{\mathrm{c}} p<0.005$

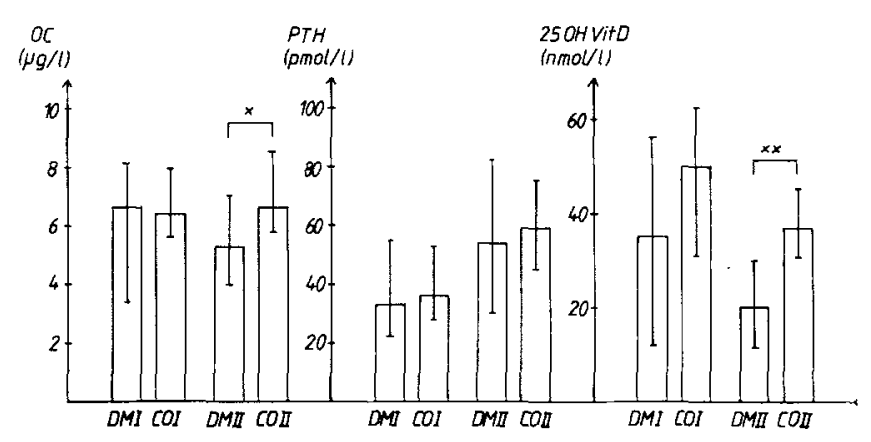

Fig. 1. Median serum levels of osteocalcin (OC), parathyroid hormone (PTH) and 25 hydroxy vitamin D (25 OH Vit.D) in Type 1 (DM I) and Type 2(DM II) diabetic patients and corresponding control groups (CO I/CO II): Vertical lines (I) indicate the lower and the upper quartiles. $* p<0.03 ;{ }^{* *} p<0.001$

habits. As a circadiane rhythm of $O C$ in human serum has been described [15], blood samples in diabetic patients and control subjects were obtained between 08.00 and $08.30 \mathrm{~h}$ in the fasting state before the insulin injections or the oral hypoglycaemic medication was given. Blood sampling in the patients and controls was equally distributed throughout the year. Serum levels of OC, PTH and $25 \mathrm{OH}$ Vit. D were measured by specific radioimmunoassays as described in detail earlier [16]. Serum OC levels were determined by a commercially available radioimmunoassay kit (CIS International, Gif sur Yvette, France). Serum levels of parathyroid hormone were measured by a radioimmunoassay of mid-regional specificity (Sorin Biomedica, Saluggia, Italy). Serum levels of $25 \mathrm{OH}$ Vit. D were determined by competitive binding protein assay after extraction and C-18 purification (Radiochemical Center, Amersham, UK).

All radioimmunoassays had intra-assay coefficients of variation in the useful range of the assays of less than $8 \%$ and interassay coefficients of variation of less than $14 \%$. The minimal detectable concentration of OC was $0.2 \mu \mathrm{g} / \mathrm{l}$, of PTH $20 \mathrm{pmol} / 1$ and of $25 \mathrm{OH}$ Vit.D $3.7 \mathrm{nmol} / \mathrm{l}$. Serum levels of bilirubin, alkaline phosphatase (AP), aspartate aminotransferase (GOT), alanine aminotransferase (GPT), $\gamma$ glutamyltransferase $(\gamma \mathrm{GT})$ and creatinine were determined by an American Monitor Parallel Analyser, Indianapolis, Indiana, USA.

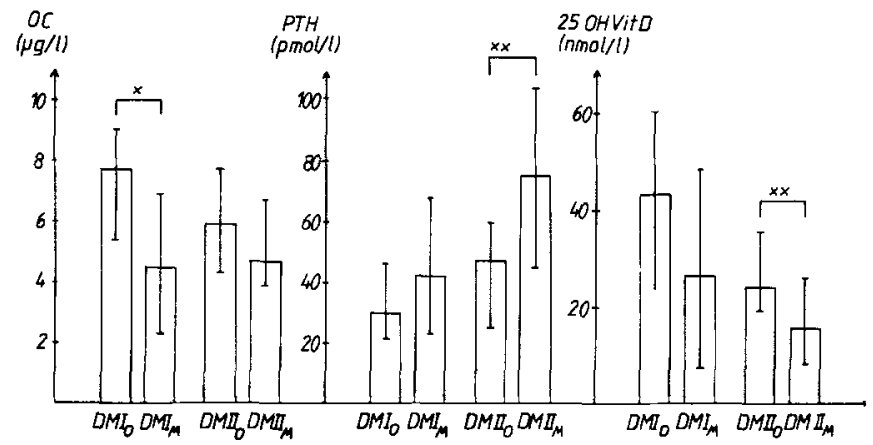

Fig. 2. Median serum levels of osteocalcin (OC), parathyroid hormone (PTH) and 25 hydroxy vitamin D (25 OH Vit. D) in Type 1 (DM I) and Type 2 (DM II) diabetic patients with (M) and without (O) diabetic microangiopathic complications. Vertical lines (I) indicate the lower and the upper quartile. ${ }^{*} p<0.05 ; * * p<0.02$

\section{Statistical analysis}

Unless indicated otherwise all the data in the text and the tables are given as the mean \pm SEM. The Kruskal-Wallis test and Kendall Tau correlation coefficient were used for statistical analysis.

\section{Results}

Figure 1 shows the serum levels of OC, PTH and $25 \mathrm{OH}$ Vit. D in Type 1 and Type 2 diabetic patients and in the corresponding control subjects. Serum levels of OC, PTH and $25 \mathrm{OH}$ Vit. D in Type 1 diabetic patients and age matched control subjects were not statistically different. In Type 2 diabetic patients serum levels of $O C$ and $25 \mathrm{OH}$ Vit. D were significantly lower $(p<0.001)$ than in the corresponding control subjects. Whereas in the Type 2 diabetic patients serum levels of bilirubin, AP, GOT, GPT and $\gamma \mathrm{GT}$ were not statistically different 
from the corresponding controls, the Type 1 diabetic patients had significantly higher levels of AP and GPT ( $p<0.04$ and $p<0.03$, resp.) than the age matched control subjects, although all values were within the normal range of our laboratory (Table 2). In the Type 2 diabetic patients serum calcium levels were slightly but significantly lower than $(p<0.005)$ in the corresponding control group (Table 2).

In addition, we evaluated serum levels of $\mathrm{OC}, \mathrm{PTH}$, $25 \mathrm{OH}$ Vit. D in diabetic patients without signs of diabetic microangiopathy in comparison with diabetic patients with retinopathy and/or proteinuria (Fig. 2). Serum creatinine levels and creatinine clearances in the Type 1 and Type 2 diabetic patients with and without microangiopathic complications were not statistically different (serum creatinine: $0.8 \pm 0.05$ vs $0.9 \pm 0.06$ $\mathrm{mg} / \mathrm{dl} \mathrm{NS}$ and $0.9 \pm 0.04$ vs $1.0 \pm 0.07$ NS resp.; creatinine clearance: $91 \pm 8$ vs $85 \pm 12 \mathrm{ml} / \mathrm{min}$ NS and $82 \pm 10$ vs $73 \pm 8 \mathrm{ml} / \mathrm{min}$ NS respectively). Serum levels of $O C$ were significantly lower in Type 1 diabetic patients with retinopathy and/or proteinuria when compared with Type 1 diabetic patients without signs of microangiopathy. Serum levels of OC in Type 2 diabetic patients with microangiopathy were slightly lower than in Type 2 diabetic patients without microangiopathy, however, the differences did not reach statistical significance. Whereas in Type 1 diabetic patients with and without microangiopathy serum PTH and $25 \mathrm{OH}$ Vit. D levels were not statistically different, in Type 2 diabetic patients with retinopathy and/or proteinuria decreased serum levels of $25 \mathrm{OH}$ Vit. D and increased serum levels of PTH were found (Fig. 2). In Type 1, as well as in Type 2 diabetic patients with and without signs of microangiopathy, serum levels of bilirubin, GOT, GPT, AP and $\gamma$ GT were not statistically different (data not shown).

Both in Type 1 and Type 2 diabetic patients, no significant correlation between serum $O C$ levels and $\mathrm{HbA}_{1 \mathrm{C}}$ could be found $(\mathrm{tau}=-0.05$, NS and tau $=$ -0.18 , NS respectively).

\section{Discussion}

Our data demonstrate that serum OC levels are decreased in patients with Type 2 diabetes mellitus and in Type 1 diabetic patients with retinopathy and/or proteinuria. Serum OC levels have been found to be a biochemical marker of bone formation: in conditions with increased bone formation such as in primary hyperparathyroidism, in hyperthyroidism or in high-turnover osteoporosis serum OC levels are increased [12, 14, 17].

In turn, in conditions with decreased bone formation such as in patients receiving glucocorticoids or in low-turnover osteoporosis, OC levels have been found to be decreased $[14,17]$. Our findings of low $O C$ levels in Type 2 diabetic patients and Type 1 diabetic patients with diabetic microangiopathy thus indicate that bone formation is decreased in these patients. Our results are in line with histological studies demonstrating a diminished rate of bone formation in diabetes mellitus [18, 19]. In a very recent paper, Ishida et al. found decreased serum OC levels and a decreased bone content of OC in streptozocin-induced diabetic rats [20]. The pathomechanism leading to a decreased bone formation in diabetes mellitus has not been fully clarified until now. As insulin stimulates the uptake of amino acid and the collagen synthesis in bone [21,22], insulin deficiency might be one possible etiologic factor of diabetic osteopathy.

In the Type 1 diabetic patients with retinopathy and/or proteinuria serum OC levels were lower than in Type 1 diabetic patients without signs of microangiopathy. These differences might be due, at least in part, to changes in the life style or morbility in the patients with late complications. However, as diabetic microangiopathy has been found also to be manifest in the vascular system of bone marrow [23], it might be speculated that diabetic microangiopathy could influence bone formation, perhaps via a disturbed bone vascularisation. In Type 1 diabetic patients, serum levels of AP were higher than in the control group. However, AP has been found to be a less specific and a less sensitive marker of bone turnover than serum OC levels [14]. As in Type 1 diabetic patients, GPT was significantly higher than in the control group, it is probable that the elevated levels of AP in these patients are caused by contributions from extraosseous e.g. hepatic tissue [24].

In the literature on diabetes mellitus, both normal and altered concentrations of mineral regulating hormones have been reported [25-27]. In the Type 1 diabetic patients in agreement with previous data [28-30], serum levels of total calcium, phosphorus, PTH and $25 \mathrm{OH}$ vitamin D were not statistically different from the matched control group. In the Type 2 diabetic patients, while median serum PTH levels were similar to those of the control subjects, serum calcium and the levels of $25 \mathrm{OH}$ Vit. $\mathrm{D}$, which is the main circulating form of the vitamin and represents the body stores of vitamin D [31], were significantly decreased. When Type 2 diabetic patients were subdivided into those with and without signs of microangiopathic complications, serum $25 \mathrm{OH}$ Vit. D levels were lower in patients presenting with retinopathy and/or proteinuria. In the latter group - propably due to the more severe vitamin D deficiency - serum levels of PTH were significantly higher than in the Type 2 diabetic patients without diabetic microangiopathic complications. The lower $25 \mathrm{OH}$ Vit. D levels in the Type 2 diabetic patients might be due to a decreased UV exposure, to a decreased dietary vitamin $\mathrm{D}$ intake or a diminished intestinal absorption of vitamin $\mathrm{D}$, possibly aggravated by diabetic autonomic neuropathy.

In conclusion, the data of our study demonstrate a vitamin $D$ deficiency and decreased serum OC levels in Type 2 diabetes mellitus; in Type 1 diabetic patients, 
serum $\mathrm{OC}$ levels are lower in patients with microangiopathic complications than in patients without evidence of microangiopathy.

\section{References}

1. Morrison LB, Bogan IK (1927) Bone development in diabetic children: a roentgen study. Am J Med Sci 174: 313

2. Menczel J, Makin M, Robin G, Joye I, Naor E (1972) Prevalence of diabetes mellitus in Jerusalem. Its association with presenile osteoporosis. Isr J Med Sci 8: 918-919

3. Meema HE, Meema $S$ (1967) The relationship of diabetes mellitus and body weight to osteoporosis in elderly females. Can Med Assoc J 96: 132-139

4. Forgács A, Rosinger A, Vértes L (1976) Diabetes mellitus and osteoporosis. Endocrinologie 67: 343-350

5. Levin ME, Boisseau VC, Avioli LV (1976) Effects of diabetes mellitus on bone mass in juvenile and adult-onset diabetes. $\mathrm{N}$ Engl $\mathrm{J}$ Med 294: 241-245

6. Santiago JV, McAllister WH, Ratzan SK, Bussman Y, Haymond MW, Shackelford G, Weldon VV (1977) Decreased cortical thickness and osteopenia in children with diabetes mellitus. J Clin Endocrinol Metab 45: 845-848

7. McNair P, Madsbad S, Christensen MS, Christiansen C, Faber OK, Binder C, Transbol I (1979) Bone mineral loss in insulintreated diabetes mellitus: studies on pathogenesis. Acta Endocrinol (Copenh) 90: 463-472

8. McNair P, Madsbad S, Christiansen C, Faber OK, Transbol I, Binder C (1978) Osteopenia in insulin treated diabetes mellitus: its relation to age at onset, sex and duration of disease. Diabetologia 15: $87-90$

9. Shore RM, Chesney RW, Mazess RB, Rose PG, Bargman GJ (1981) Osteopenia in juvenile diabetes. Calcif Tissue Int 33: 455-457

10. Wiske PS, Wentworth SM, Norton JA Jr, Epstein S, Johnston CC $\mathrm{J}_{\mathrm{r}}$ (1982) Evaluation of bone mass and growth in young diabetics. Metabolism 31: 848-854

11. Leeuw I de (1977) Bone mass and bone density in maturity-type diabetics measured by the ${ }^{125} \mathrm{I}$ photon-absorption technique. Diabetes 26: 1130-1135

12. Price PA, Parthemore JG, Deftos LJ, Nishimoto SK (1980) New biochemical marker for bone metabolism: measurement by radioimmunoassay of bone GLA protein in the plasma of normal subjects and patients with bone disease. J Clin Invest 66: 878-883

13. Price PA, Williamson MK, Lothringer JW (1981) Origin of the vitamin $\mathrm{K}$-dependent bone protein found in plasma and its clearance by kidney and bone. J Biol Chem 256: 12760-12766

14. Brown JP, Delmas PD, Malaval L, Edouard C, Chapuy MC, Meunier PJ (1984) Serum bone GLA-protein: a specific marker for bone formation in postmenopausal osteoporosis. Lancet I: $1091-1093$

15. Gundberg CM, Markowitz ME, Mizruchi M, Rosen IF (1985) Osteocalcin in Human Serum: A Circadian Rhythm. J Clin Endocrinol Metab 60: 736-739

16. Pietschmann P, Woloszczuk W, Panzer S, Kyrle P, Smolen J (1988) Decreased serum osteocalcin levels in phenprocoumontreated patients. J Clin Endocrinol Metab 66: 1071
17. Lukert BP, Higgins JC, Stoskopf MM (1986) Serum osteocalcin is increased in patients with hyperthyroidism and decreased in patients receiving glucocorticoids. J Clin Endocrinol Metab 62: 1056-1058

18. Kelin M, Frost HM (1964) The numbers of bone resorption and formation foci in rib. Henry Ford Hosp Med Bull 12: 527-536

19. Wu K, Schubeck KE, Frost HM, Villanueva A (1970) Haversian bone formation rates determined by a new method in a mastadon, and in human diabetes mellitus and osteoporosis. Calcif Tissue Res 6: 204-219

20. Ishida H, Seino Y, Taminato T, Usami M, Takeshita N, Seino Y, Tsutsumi C, Moriuchi S, Akiyama Y, Hara K, Imura H (1988) Circulating levels and bone contents of bone carboxyglutamic acidcontaining protein are decreased in streptozocin-induced diabetes. Diabetes 37: 702-706

21. Hahn TJ, Downing SJ, Phang JM (1971) Insulin effect on amino acid transport in bone: dependence on protein synthesis and $\mathrm{Na}^{+}$. Am J Physiol 220: 1717-1723

22. Wettenhall REH, Schwartz PL, Bornstein J (1969) Actions of insulin and growth hormone on collagen and chondroitin sulfate synthesis in bone organ cultures. Diabetes 18: $280-284$

23. Bartl R, Moser W, Burkhardt R, Sandel P, Kamke W, Mähr G, Adelmann BC (1978) Diabetische Osteomyelopathie: histobioptische Befunde an Knochen und Knochenmark bei Diabetes mellitus. Klin Wochenschr 56: 743-754

24. Camerini-Davalos R, Marble A, Muench H (1962) Liver function in diabetes mellitus. $\mathrm{N}$ Engl J Med 266: 1349-1354

25. Fogh-Andersen N, McNair P, Moller-Petersen J, Madsbad S (1982) Serum calcium fractions in diabetes mellitus. Clin Chem 28: $2073-2076$

26. Witt MF, White NH, Santiago JV, Seino Y, Avioli LV (1983) Use of oral calcium loading to characterize the hypercalciuria of young insulin-dependent diabetics. J Clin Endocrinol Metab 57: 94-99

27. Storm TL, Sorensen OH, Lund BJ, Christiansen JS, Andersen AR, Lumholtz IB, Parving HH (1983) Vitamin D metabolism in insulin-dependent diabetes mellitus. Metab Bone Dis Relat Res 5: 107-110

28. Heath H, Lambert PW, Service FJ, Arnaud SB (1979) Calcium Homeostasis in Diabetes Mellitus. J Clin Endocrinol Metab 49: $462-466$

29. Nyomba BL, Bouillon R, Bidingija M, Kandjingu $\mathrm{K}$, Moor $\mathrm{P}$ de (1986) Vitamin $D$ metabolites and their binding protein in adult diabetic patients. Diabetes 35:911-915

30. Auwerkx J, Dequeker J, Bouillion R, Geusens P, Nijs J (1988) Mineral metabolism and bone mass at peripheral and axial skeleton in diabetes mellitus. Diabetes 37: 8-12

31. Tsai KS, Wahner HW, Offord KP, Melton III LJ, Kumar R, Riggs BL (1987) Effect of aging on Vitamin D stores and bone density in women. Calcif Tissue Int 40:241-243

Received: 1 July 1988

and in revised form: 17 October 1988

Dr. P. Pietschmann

Department of Medicine II

Garnisongasse 13

A-1090 Vienna

Austria 